\title{
ディーゼル排ガス吸入曝露によるマウス肺胞上皮細胞の変化を示す電顕写真
}

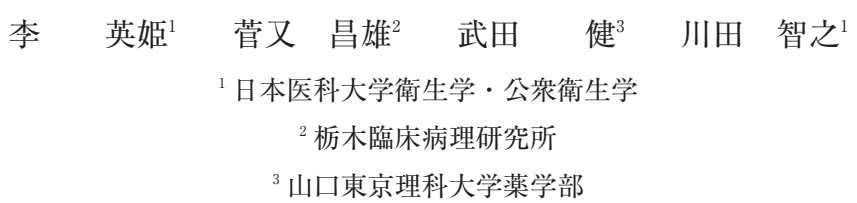

\section{Changes of Mouse Alveolar Epithelial Cells by Diesel Exhaust Gas Inhalation Exposure in Electron Micrograph}

\author{
Ying-Ji Li ${ }^{1}$, Masao Sugamata ${ }^{2}$, Ken Takeda ${ }^{3}$ and Tomoyuki Kawada ${ }^{1}$ \\ ${ }^{1}$ Department of Hygiene and Public Health, Nippon Medical School \\ ${ }^{2}$ Tochigi Institute of Clinical Pathology \\ ${ }^{3}$ Faculty of Pharmaceutical Sciences, Sanyo-Onoda City University
}

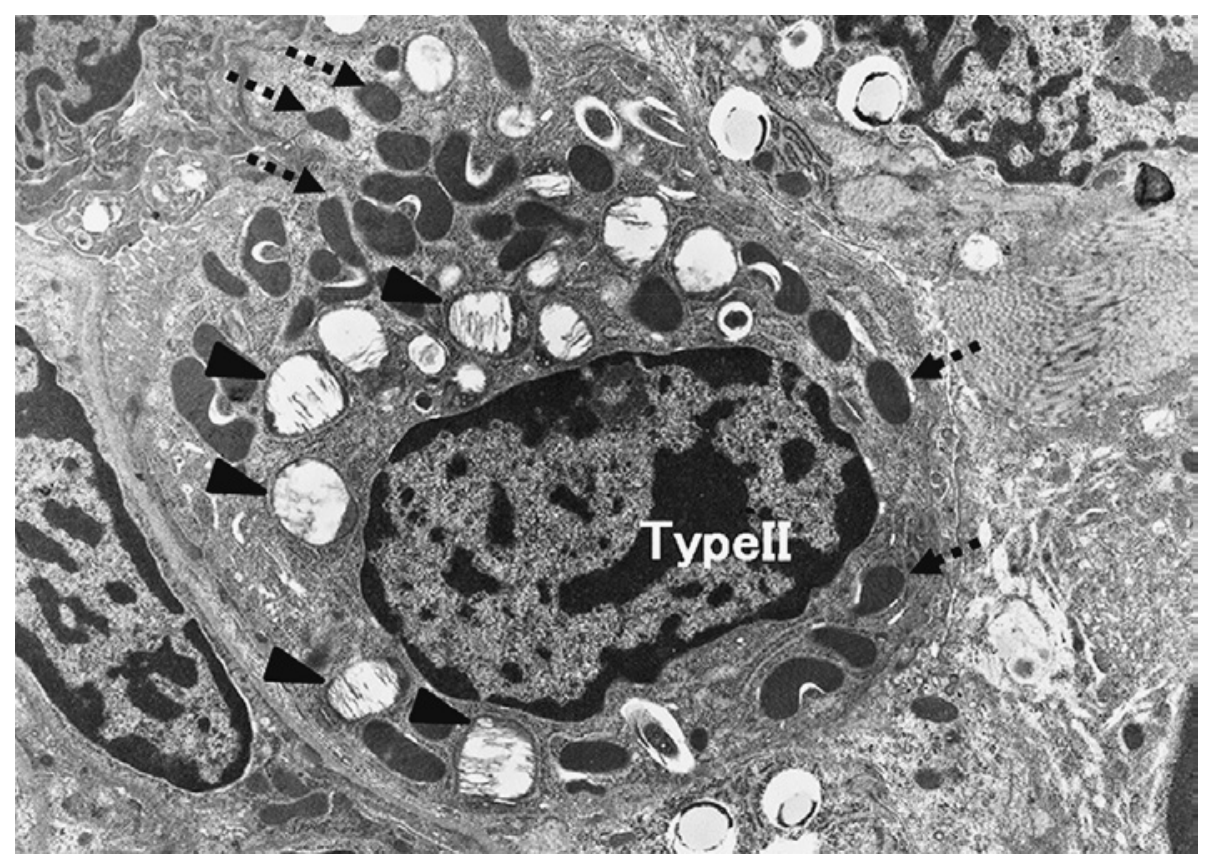

図 1 コントロール群

ディーゼル排ガス（DE，Diesel Exhaust）に含まれてい る粒子（DEP, Diesel Exhaust Particles）の大部分は重量 的には微小粒子状物質 $\left(\mathrm{PM}_{2.5}\right)$ であり，個数的には超微小 粒子状物質 $\left(\mathrm{PM}_{0.1}\right)$ である. 粒子径が小さいほど肺の奥深 くまで入りやすい，われわれは，C57BL/6J マウスを用い， コントロール群 (清浄空気), DE 曝露群（DEP 濃度 $1 \mathrm{mg}$ / $\left.\mathrm{m}^{3}\right)$ を設定し, DE 吸入曝露を行い, 曝露 4 週目に肺組織 を採取し，電顕による肺組織の形態学的変化について検討 した．図 1 では，コントロール群の肺組織の II 型肺胞上皮
細胞を示す．細胞質にミトコンドリアと同心円状の層板構 造を有したラメラボディー (lamellar body) がみられる. ラメラボディーからは表面活性物質である肺サーファクタ ントが産生される1. 図2 では, DE 曝露群の肺組織の II 型 肺胞上皮細胞を示す.コントロール群と比較し, ラメラボ ディーの明らかな形態的変化がみとめられ，ラメラボ ディーの変性所見とみられる。 また, 肺胞上皮細胞のアポ トーシスを示唆する所見がみられる。核は陥入し，断片化 するために摘み取られ (irregular-condensed chromatin

連絡先： $\bar{\top} 113-8602$ 東京都文京区千駄木 1-5-5 日本医科大学衛生学・公衆衛生学

Email: li-yingji@nms.ac.jp

Journal Website (http://www2.nms.ac.jp/jmanms/) 


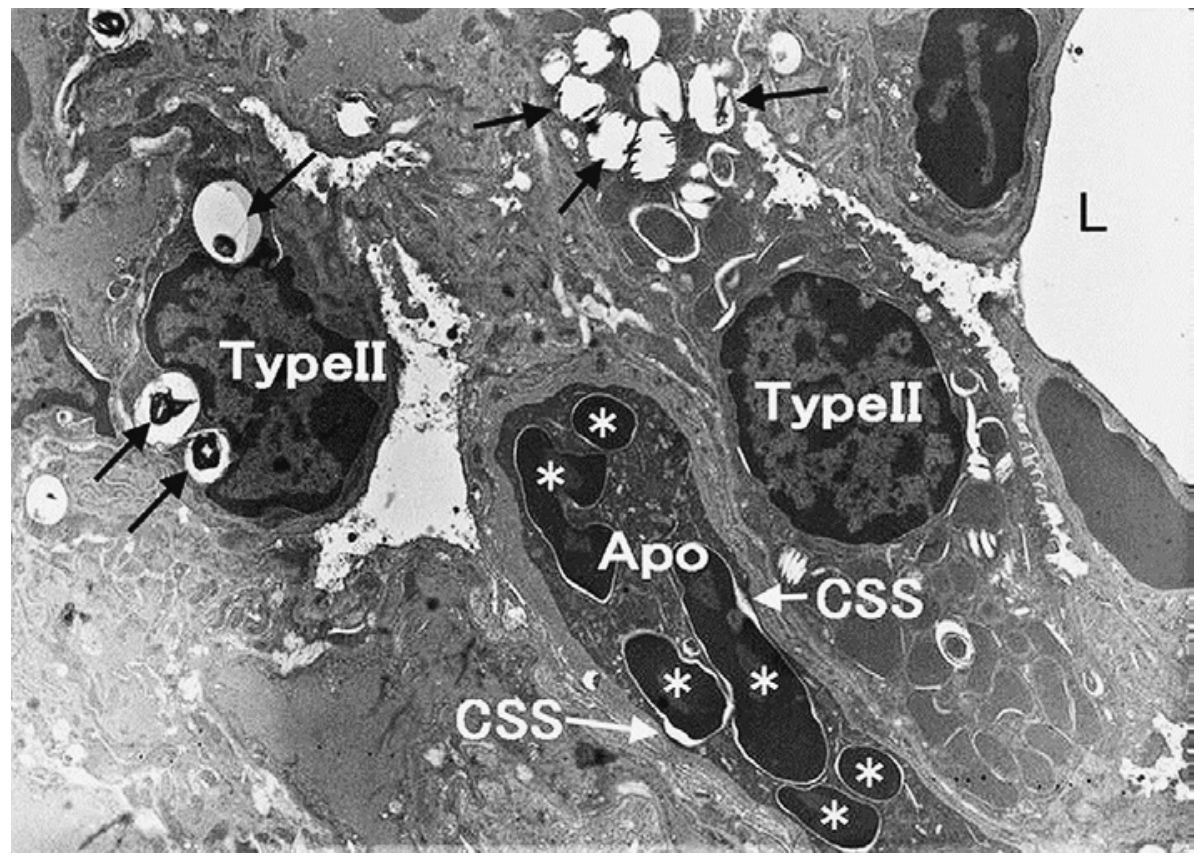

図 2 DE 曝露群

and nuclear fragmentation), 細胞の核エンベロープの周り に三日月形の空間（crescent-shaped spaces, CSS）が観察 される. CSS 所見はアポトーシスを引き起こす初期段階に おける細胞核の周りに現れることは報告されている2.アポ トーシスが誘導されているため, 細胞の分類（I 型または

図 1 コントロール群の肺組織の II 型肺胞上皮細胞 (Type II）を示す. 細胞核周囲の細胞質にラメラボディー（アロー ヘッド）とミトコンドリア (黒い点線矢印) がみられる.

図 2 DE 曝露群の肺組織の II 型肺胞上皮細胞（Type II）

\section{文 献}

1. Cross PC, Mercer KL: Cell and Tissue Ultrastructure. 1993; pp 314-315, W.H. Freeman and Company, New York.

2. Ihara T, Yamamoto T, Sugamata M, Okumura H, Ueno Y: The process of ultrastructural changes from
II 型）についての判断は難しい. in vitro 研究において, DEP は酸化ストレス作用によりアポトーシスを誘発する ことが報告されており ${ }^{3}$, 本実験系においても，DE 吸入曝 露により, 肺胞上皮細胞のアポトーシスが誘導されること が示唆された。

を示す. ラメラボディーの変性所見 (黒い矢印), および核 の断片化 $(*)$ ，三日月形の空間（CSS，白い矢印）など肺 胞上皮細胞のアポトーシス (Apo) を示唆する所見が観察 される. L : lumen（肺胞腔）

nuclei to apoptotic body. Virchows Arch 1998; 433: 443-447.

3. Tseng CY, Wang JS, Chao MW: Causation by diesel exhaust particles of endothelial dysfunctions in cytotoxicity, pro-inflammation, permeability, and apoptosis induced by ROS generation. Cardiovasc Toxicol 2017; 17: 384-392. 